\title{
Language And Gender In Teen Short-Stories
}

\author{
Dwi Indarti \\ Email: dwi.diw@bsi.ac.id
}

\author{
Cara Sitasi: \\ Indarti, D. (2018). Language And Gender In Teen Short-Stories. Wanastra, 10(2), 85-90.
}

\begin{abstract}
This study aims to investigate the differences of language use between two short-stories published in two teen magazines which represent gender. According to the content, context, and segment readers, HAI magazine is considered as teen male magazine while KAWANKU is considered as teen female magazine. The results of this study confirm the theory of gender in writing production proposed by Coates (1993) who stated that men tend to use a report style aiming to communicate factual information, whereas women more often use a rapport style which is more concerned with building and maintaining relationships. The two short-stories in HAI and Kawanku reflect the issue of gender construction in society through written discourse. Gendered language that occurs in the literary works such as short-story declare that the differences between male and female way of speak can be found in written texts.
\end{abstract}

Keywords: Sociolinguistic; Gender; Short-stories

\section{INTRODUCTION}

The study of different use of language especially between male and women has been one of the important aspects in the sociolinguistics study. The well-known different use characteristic language use between male and women phenomena in written language have been favourite topics for some researchers in the study of relationship between language and society. Writing is a rich medium for gender performance (Mulac \& Lundell in Janssen \& Murachver: 1994). In the study of New Zealand fiction, Janssen and Murachver (2004a) found that female and male authors differed in their language use. Similarly, language used by authors of popular and award-winning fiction differed systematically. The way that authors try to deliver their writing can be found in the magazine. One part of magazine that gives a space to authors to express their written language is in the short stories section. A considerable amount of research have noted that language in male and women short story is different, but little research have exploded the noise of different language and gender used in short-stories especially in teen magazine. In Indonesia, many teen magazines are published their edition either in weekly or monthly kind of issue, for examples Kawanku which is more familiar as a magazine related to girls' life and HAI which is known as boys' magazines are two kinds of magazines that publish some spaces for short stories section. Kawanku is a girl's magazine which published their first edition in 1970. This magazines focuses on teen reader aged around 11 until 19 years old. There are fashion, mode, make up and beauty, celebrities news, girls' activities, tips for girls, and zodiac served to the reader in this magazine. This magazine consists of 130 until 140 pages per edition which publish once a week especially in every Wednesday.
Meanwhile, HAI magazine found in the 1977 and the first edition of this magazine was 36 pages which dominated by comic stories. In the $1980 \mathrm{~s}$, video, film and TV were booming and HAI took that opportunity to put the review and synopsis as content in the magazine. 1990s were the "very it" era for $H A I$ as a one of reputable magazine in Indonesia. A lot of young talented authors born from this magazine and many memorable stories published in that era like Lupus, Balada si Roy, and Anak-anak Alin. In the 2000 s passed the $30^{\text {th }}$ year of phase as a boy's magazine which still focuses on male readers and aged between 11-19 years old. Today, the variety content of this magazine rubrics starts from sport, automotive, gadget, school, music, fashion for boys, games, until photography. This magazine consists of 95 until 100 pages per edition which publish once a week, especially every Monday.

One of the sections that are very interesting in both magazines above is short-story. These two magazines give different requirement for writers who want to send their short story in that magazine. The specifications of the topic used in two magazines are also different. Most of Kawanku serves the "girl's kind of life" in the short-story. One of the stories that are very interested is "Effortlessly Beautiful" written by Nadia safira. This is one of the stories that reflect about teenage girl's life and their problems. Meanwhile, in HAI Magazine, Koko Ferdie wrote "Selamat Tinggal, Cinta" which related to boys' life and their stories.

Based on the explanation above, the writer decided to find out the differences of two short-stories in Indonesian Teen Magazines especially in HAI and Kawanku related to the characters. The question remains the differences of characters in the two short-stories in Indonesian teen magazines $H A I$ and 
$K A W A N K U$ and how it relates to language and gender analysis. The goal of this study is to determine the differences between boy's characters and girl's characters in the two short-stories in teen magazines, in the term of the using of words, dialogues, narrations and theme.

It is best to review some related literatures and previous studies to get a proper basic comprehension before moving on further discussions. An issue about constructing gender identities of two short stories has ever been conducted by Shaikh \& Khan (2012). The research investigates the issue of gender construction in society through written discourse. It analyses about two short stories by a Pakistani writer Haris Khalique and an Indian writer Rohini Kohli selected from their collection of stories titled Unfinished Histories. The research method followed by this study is Critical Discourse Analysis. By applying CDA as a general methodology, this research has tried to investigate the relationship between discourse and social practices pertaining to construction of gender identity. The finding was females role are shown to be more interested in the domestic side of life, having more to do with households and romance than intellectual aspect of life, which is presented as men's domain, who are thought of as intellectually higher than their female counterparts. The same issue is analysed by Chang (2016) discussed about gendered language in five recent short stories written by Japanese women in English translation. She examines how the writers interact with the culturally loaded concept of gendered language to develop characters and themes. Gendered styles are central to the stories and translators wishing to follow closely to the source text should pay close attention to the issue. They are used in a variety of ways such as in dialogue, to index social identity, to highlight the differences between social and inner self, and different styles are mixed together for emphasis.

Maltz and Borker's (1982) give the model of gender-marked language. They distinguish between male and female speech. Male speech is dominated by competition oriented or adversarial, attracting and maintaining an audience and asserting themselves when other speakers have the floor. However, female speech is characterized with collaboration oriented, using language more cooperatively than males, responding to and elaborating on what others have said, making more supportive comments, asking more questions, working to keep conversations going, to create and maintain relationships of closeness and equality. Coates (1993) also explains more about gender-language. She argues that men tend to use a report style aiming to communicate factual information, whereas women more often use a rapport style which is more concerned with building and maintaining relationships. De Francisco (1991) points out that female behavior encloses a desire to take turns in conversation with others which is opposed to men's tendency towards centering on their own point. Maltz and Borker's (1982) emphasize the same point with Victoria that males use language primarily to assert their position of dominance.

Beside the language which differentiation between male's and female's communication, the way male and female solve their conflicts are also different. According to Gilligan (1982), the conflict style of males has a justice orientation. Whatever the problem is, males always try to solve their conflict fairly. It shows their dignity and their power as men. That can be the reason why males value logic and rationally while attempting to resolve conflict through rules or reason. In contrast to female, their conflict has a caring orientation because they focus on the relationship. They prefer to maintain connections with others than ruining their friendship. Females' conflict style also indicates that they use more collaborative speech acts and pay more attention to the needs of others.

\section{RESEARCH METHODOLOGY}

This research used case study because the writers limited the data using two short stories from famous magazines in Indonesia which are HAI and KAWANKU magazines. The objective of this study investigates how characters' differences relate to language and gender analysis in short-stories published in HAI and KAWANKU. The two short stories of HAI (Boy's Magazine) titled "Selamat Tinggal, Cinta" written by Koko Ferdie and KAWANKU (Girl's Magazine) titled "Effortlessly Beautiful" written by Nadia Safira. The writers collected the data by analyzing the short stories and using some related theories to see the characters' differences which relate to language and gender.

\section{RESULTS AND DISCUSSIONS}

The results of the data collection show the significant differences between boy's and girl's short-story. Table. 1 below presents the analyses of two short stories.

Table.1. Data of two short-stories

\begin{tabular}{|l|l|l|}
\hline & HAI & KAWANKU \\
\hline $\begin{array}{l}\text { Segment } \\
\text { readers }\end{array}$ & Teenage boys & Teenage girls \\
\hline Age & $\begin{array}{l}11-19 \text { years } \\
\text { old }\end{array}$ & $\begin{array}{l}11-19 \text { years } \\
\text { old }\end{array}$ \\
\hline Content & $\begin{array}{l}\text { Sport, } \\
\text { automotive, } \\
\text { music, games, }\end{array}$ & $\begin{array}{l}\text { Fashion, mode, } \\
\text { beauty and } \\
\text { make up, }\end{array}$ \\
\hline
\end{tabular}




\begin{tabular}{|c|c|c|}
\hline & photography & celebrities \\
\hline Pages & $\begin{array}{l}95-100 \text { pages } \\
\text { per edition }\end{array}$ & $\begin{array}{ll}130- & 140 \\
\text { pages } & \text { per } \\
\text { edition } & \end{array}$ \\
\hline Published & Once a week & Once a week \\
\hline Short-story & $\begin{array}{l}\text { Selamat } \\
\text { tinggal, Cinta }\end{array}$ & $\begin{array}{l}\text { Effortlessly } \\
\text { Beautiful }\end{array}$ \\
\hline Author & Koko Ferdie & Nadia Safira \\
\hline $\begin{array}{l}\text { Published } \\
\text { edition }\end{array}$ & $\begin{array}{l}20-26 \\
\text { October } 2017\end{array}$ & $\begin{array}{l}15-29 \\
\text { October } 2017\end{array}$ \\
\hline $\begin{array}{l}\text { Characters } \\
\text { with space }\end{array}$ & 6.618 & 8.452 \\
\hline Words & 1.195 & 1.532 \\
\hline Dialogues & 41 & 27 \\
\hline Narrations & 20 & 36 \\
\hline Self Reference & Gue & $\mathrm{Aku}$ \\
\hline $\begin{array}{l}\text { Code- } \\
\text { switching }\end{array}$ & 31 & 5 \\
\hline $\begin{array}{l}\text { Example of } \\
\text { dialogues }\end{array}$ & $\begin{array}{l}\text { "Lo nggak } \\
\text { papa, man?" }\end{array}$ & $\begin{array}{lr}\text { "Makalah. } & \text { "Aku } \\
\text { takut } & \text { besok } \\
\text { enggak } & \text { bisa } \\
\text { bantuin } & \text { Ladya } \\
\text { soalnya } & \text { kan } \\
\text { weekend } & \text { mau } \\
\text { ada } & \text { gigs, } \\
\text { takutnya } & \\
\text { dipanggil rapat } \\
\text { dadakan. Jadi } \\
\text { besok } & \text { Ladya } \\
\text { engga repr." } & \text { usah } \\
\text { repot. } & \end{array}$ \\
\hline $\begin{array}{l}\text { Example of } \\
\text { narrations }\end{array}$ & 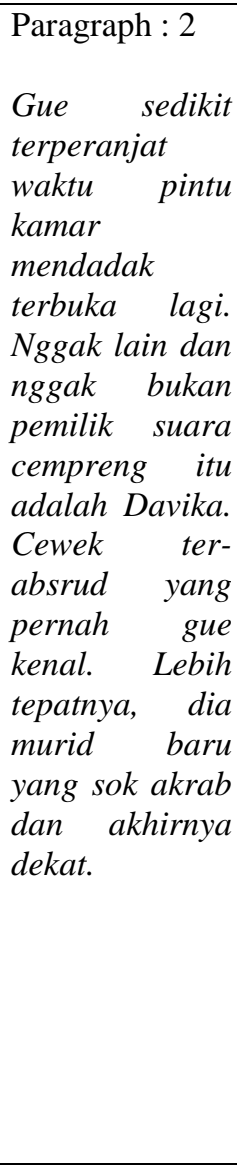 & $\begin{array}{l}\text { Paragraph : } 2 \\
\text { Tapi coba } \\
\text { kalian lihat } \\
\text { Ladya. Geek } \\
\text { manis dengan } \\
\text { poni lurus dan } \\
\text { kacamata } \\
\text { besar. Bahkan } \\
\text { tanpa effort } \\
\text { pun dia terlihat } \\
\text { menawan. Setip } \\
\text { hari Ladya } \\
\text { selalu datang } \\
\text { hampir } \\
\text { bersisian } \\
\text { denganku } \\
\text { karena - well- } \\
\text { kita sama-sama } \\
\text { penggemar } \\
\text { suara bel } \\
\text { sekolah, } \\
\text { hampir } \\
\text { terlambat } \\
\text { sudah bukan } \\
\text { hal baru lagi } \\
\text { bagi kami. } \\
\text { Bedanya, } \\
\text { setelah }\end{array}$ \\
\hline
\end{tabular}

\begin{tabular}{|c|c|c|}
\hline & & 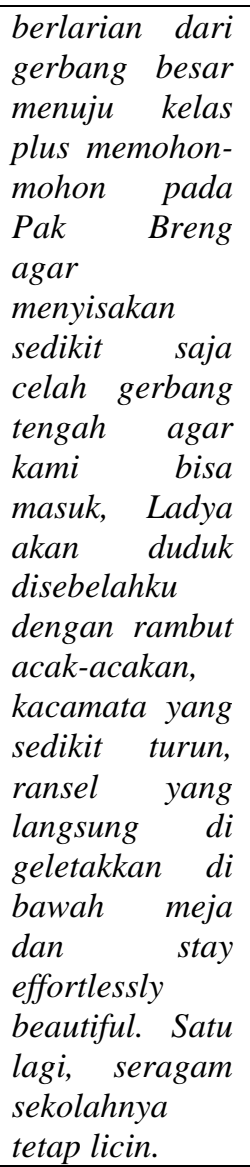 \\
\hline Opening Act & $\begin{array}{l}\text { "Jangan } \\
\text { tawuran lagi!" }\end{array}$ & 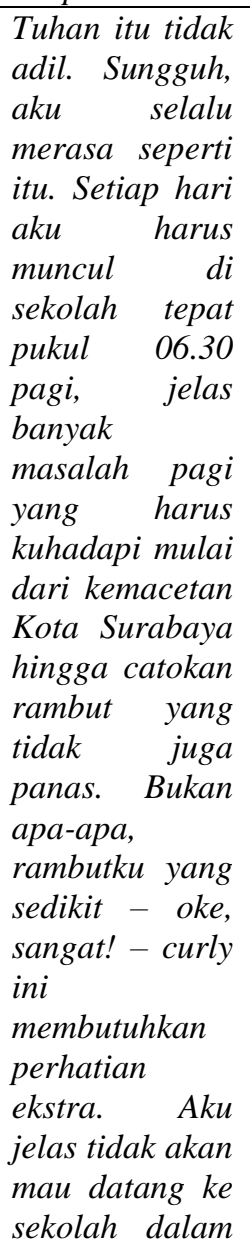 \\
\hline
\end{tabular}




\begin{tabular}{|c|c|c|}
\hline & & $\begin{array}{l}\text { keadaan } \\
\text { rambut selebar } \\
\text { sarang burung. }\end{array}$ \\
\hline $\begin{array}{l}\text { Main } \\
\text { characters }\end{array}$ & $\begin{array}{l}\text { Dyko } \\
\text { High school } \\
\text { student } \\
\text { A rebel boy } \\
\text { Has a } \\
\text { dangeours } \\
\text { hobby } \\
\text { fighting }\end{array}$ & $\begin{array}{l}\text { Lou } \\
\text { High school } \\
\text { student } \\
\text { Always feel } \\
\text { jealous to her } \\
\text { best friend }\end{array}$ \\
\hline
\end{tabular}

The amount of the characters of short-story titled "Selamat tinggal, Cinta, in HAI magazine are less than in Kawanku. HAI's short-story consists of 6.618 characters, while Kawanku's short-story consists of 8.452 characters. The same case also accurs in the amount of words. Kawanku uses more words than HAI. HAI's short-story consists of 1.195 words, while Kawanku's short-story consists of 1.532 words. Those evidences refer to statement of Maltz and Borker (1982) who state a model of gender-marked language about male and female speech character. Some of female speech characterizes that they use language more cooperatively than males and respond to and elaborate on what others have said.

The main character in HAI's short-story is a senior high school student, named Dyko, who is a rebel boy. Dyko has a dangerous hobby which is fighting. This characters are showed from these sentences :

1. Ya, gue emang ngebelain Bimo yang ditantang tawuran sama salah satu anak SMA gang Bengek. Masalahnya klise, cewek yang jadi rebutan. (Yes, $\mathbf{I}$ help Bimo who is challenged by one of the students from Bengek Genk. The problem is cliche, fight for the sake of a girl). Maltz and Borker's (1982) explain that male speech is dominated by competition oriented or adversarial, attracting and maintaining an audience and asserting themselves when other speakers have the floor. The sentence above shows that Dyko has fought with a Genk only because of a girl. Here, Dyko's speech indicates competition oriented. This conflict is also attracting readers to finish their reading.

2. “Jangan tawuran lagi!” Gue menengok ke samping kiri. Nyokap baru saja menutup pintu kamar, setelah menempelkan plester di dahi dan mengompres beberapa lebam di muka gue. (Don't fight anymore! I turn left. Mom has just closed the door, after put a bandage in my forehead and compress wounds in my face).

According to Gilligan (1982), the conflict style of males has a justice orientation. Whatever the problem and the result will be, males always try to solve their conflict fairly. Even it will hurt them whether it is physical injuries and emotional injuries. By fighting, they can show their dignity and their power as men. Meanwhile, Coates (1993) states that men tend to use a report style aiming to communicate factual information, whereas women more often use a rapport style which is more concerned with building and maintaining relationships. In HAI's short story, Dycko's and Devika's dialogues show report (men) and rapport style (women). Here are the analyses below.

1. "Kenapa lw menghindar?" tanya gue yang duduk di samping Devika. Kami terhalang sekat bangku perpustakaan. Dia nggak menjawab. Gue penasaran dan menggeser kursi sedikit ke belakang. "Devika Putri, Seorang yang punya cita-cita jadi penulis dan mendambakan suami seperti Keenan di film Perahu Kertas. Dan sekarang mulai jadi cewek pendiam dan nggak asik lagi”.

The sentences above are said by Dyko who is curious to know why Devika is staying away from him. He directly asks her by giving statements of factual information (report style).

2. Devika: "Dyko...!" Gue sedikit terperanjat waktu pintu kamar mendadak terbuka lagi. Nggak lain dan nggak bukan pemilik suara cempreng itu adalah Davika. Cewek ter-absurd yang pernah gue kenal. Lebih tepatnya, dia murid baru yang sok akrab dan akhirnya dekat. Dyko : "Lo nggak pernah diajarin sopan santun ya? Ketuk pintu dulu, kek!' Cewek pemilik badan bantet itu malah berkacak pinggang menatap gue. Lalu menggeleng. Dia sepertinya budek karena nggak menjawab pertanyaan gue. Devika: "Apa-apaan ini, cowok berandal bisa terkapar di kamar!” Gue tertawa sinis. Cih! Dyko: "Sejak kapan gue menyandang status sebagai cowok berandal. Perlu digaris bawahi, gue cuma kalah tawuran sekali ini doang."

Devika: "Bukan karena lo ikut-ikutan belain Bimo, kan?" Devika tiba-tiba duduk dan menepuk lengan gue. Otomatis gue menggeram kesal. Dia cuma cekikan. "Sengaja."

Dyko: "Sakit, Bantet!" Gue mendorong keningnya yang lebar.

These sentences are said by Devika who tries to keep conversation going (rapport style) with Dyko while he is is suffering because of his fighting with a Genk.

Meanwhile, the main character in Kawanku's shortstory is a senior high school student, named Lilou, who always feels jealous with her beautiful best friend. The characters are showed from these sentences: 
1. Tapi coba kalian lihat Ladya. Geek manis dengan poni lurus dan kacamata besar. Bahkan tanpa effort pun dia terlihat menawan. (But look at Ladya. A sweet girl with straight hair and big glasses. She looks effortlessly beautiful).

2. Yang membuat sedikit menyayat hati, saat aku bingung mencari kaca dan mengecek penampilanku setelah badai keterlambatan berlalu, Ladya dengan santai mengeluarkan komik Jepang edisi terbaru. Di sebelahnya? Oh itu aku yang sibuk membenahi muka dan menyisir rambut. Ladya? Tetap cantik walaupun tanpa bedak, tanpa catokan, tanpa sedikit lipgloss. (The worst is when I feel confuse to look for a mirror and see what I look like, Ladya took out a new edition of Japanese comic. While I am busy pouring my face and combing my hair. Ladya keeps looking beautiful without any make up, even just a little bit lipgloss).

3. Ladya bilang dia mau belajar dulu buat besok. Besok? Iya, besok mau bikin tugas sama Ladya, tapi Ladya bilang mau belajar dulu biar besok cepet selesainya. Ini yang membuatku iri pada Ladya. Sudah cantik, manis, pintar pula. Setiap hari dia pasti punya jam khusus belajar atau, ya, yang seperti ini. Ladya selalu minta waktu untuk belajar dulu, agar saat tugas dibuat dia enggak akan terlalu banyak bertanya dan tahu apa yang harus dilakukan. Enggak salah memang kalau banyak orang yang memperhatikannya. (Ladya said that she wants to study before tomorrow. Tomorrow? Yup, we are going to finish our assignment with Ladya, but she said she wants to study first so that we can finish our assignment early. This is what makes me envy with Ladya. She is beautiful, sweet and also smart. She has schedule time to study every day or like this way, she always asks more time to study first, so that the assignment is been doing, she will not ask more and know what to do. It is true that many people are watching her.

4. Besok-besok kalau enggak punya waktu buat bikin tugas bilang kek, kan aku jadi ngerasa bersalah bikin kamu ngerjain tugasnya sendiri sambil bikin acara besar kayak gini. (If you do not have time to do the assignment, let me know, because I feel guilty making you did the assignment by yourself while having great event like this).

From those four sentences explained above, we can find the characteristics of female's speech (Maltz and Borker: 1982) which are represented by Lilou and Ladya in this short story. In sentences 1 and 2, Lilou expresses her jealousy with Ladya who is smarter and prettier than her. The way Lilou expresses her feeling through words show that female uses language more cooperatively than males. While in sentence 3, Lilou and Ladya are trying to cooperate by doing their assignment together though Lilou has a big event to do. While Lilou permits Ladya to have more time to study for the assignment. Both of them understand their position at that time so that they can overcome their problem. In sentence 4, Ladya also makes supportive comments by giving her care and attention to her friend, Lilou. They also work to keep conversation going and maintain their relationships of closeness. This short story which is written by female writer Nadia Safira indicates that women use a rapport style (Coates; 1993) which is more concerned with building and maintaining relationships. The friendship between Lilou and Ladya has become the evidence. Though Lilou envies with Ladya's appearance and her ability, Lilou still keep maintain her relationship with Ladya. The conversations of dialogues show the tendency of both ladies in taking turn in conversation they have (De Francisco: 1991). It means they have mutual response in having conversations. Gilligan (1982) in contrast to female, their conflict has a caring orientation because they focus on the relationship. They prefer to maintain connections with others than ruining their friendship. Although, Lilou is so jealous with Ladya, but in sake of friendship, Lilou wants to do anything for Ladya, her best friend. She agreed when Ladya asked more time to study. She did not forbid her. Here, Lilou cares about Ladya. Ladya does the same. Gilligan states that females' conflict style also indicates that they use more collaborative speech acts and pay more attention to the needs of others. Lilou who is the committee of the event and is busy preparing it, Ladya came to let her know that she did the assignment herself. Ladya's action shows her attention to the needs of Lilou at that time.

The short-story in HAI contains more dialogues than in Kawanku, while Kawanku contains more narrations. In HAI's short-story, there are 41 dialogues, while in Kawanku's short-story, there are 27 dialogues. The opening statement in HAI's shortstory uses a short dialogue, while in Kawanku's short-story uses a long narration in the first paragraph. The self reference used in HAI's shortstory is 'gue' (I), and self reference used in Kawanku's short-storyis 'aku' (I). The social words found in HAI are informal words such as 'elo' (you), 'bokap' (father), 'nyokap' (mother). While in Kawanku, they use formal words for instance 'kamu' (you), 'Papa' (father), 'Mama' (mother).

There are more code switchings in Kawanku rather than in HAI. Girls tend to use code switching than boys because girl's tendency to vary the language. Kawanku's short-story consists of 31 code switchings, while HAI's short-story consists of 5 
code switchings. Kemp (2014) conducted a reasearch and the result showed that,"because of the women's brain and its tendency to ignite language, code swicthing seems like that perfect opportunity to learn to effectively communicate with men."

The dialogues in HAI's short-story use less words than in Kawanku's short-story. The example of HAI'short-story's dialogue in the paragraph 23 ,'Lo nggak papa, man?" (are you ok, man?). The example of Kawanku's short-story's dialogue in the paragraph 30, "Makalah. Aku takut besok enggak bisa bantuin Ladya soalnya kan weekend mau ada gigs, takutnya dipanggil rapat dadakan. Jadi besok Ladya engga usah repot." (Paper. I am afraid tomorrow I can't help Ladya because this weekend, there will be gigs. I am worried tomorrow will be unexpected meeting. So, Ladya does not have to busy).

\section{CONCLUSIONS}

Boy's magazine, HAI, is thinner than girl's magazine, Kawanku. HAI contains 95 - 100 pages in one edition while Kawanku contains 130 - 140 pages in one edition. It relates to the article in Tempo.com which states that ".....minat baca anak laki-laki lebih rendah ketimbang perempuan...." (Boy's reading interest is lower than girls...). The words used in HAI's short-story are less than in Kawanku's short-story. This refers to Ananda (2014) in the article from Merdeka.com that states, "Dua bagian otak yang berkaitan dengan kemampuan berbahasa terbukti lebih besar pada wanita dibandingkan pria. Tak heran jika banyak wanita yang berhasil dalam bidang yang berkaitan bahasa." (Two parts of brains that are associated with language ability shows that women have bigger part than men. No wonder that women are more successful in language field). The two shortstories in HAI and Kawanku reflect the issue of gender construction in society through written discourse. As Mullac \& Lundel (1994) stated that, "Like conversation and other modes of communication, writing is a rich medium for gender performance." Gendered language that occurs in the literary works such as short-story declare that the differences between male and female way of speak can be found in written texts.

\section{REFERENCES}

Ananda, K. S. (2014, Dec 12). 8 Perbedaan penting antara pria dan wanita. Merdeka.com. Retrieved from http://www.merdeka.com/gaya/8-perbedaanpenting-antara-pria-dan-wanita.html
Coates, J. (1993). Women, men and language. London: Longman.

Chang, J. (2016). Girls and gender in Alice Munro's short stories. Asian Women, 32(2), 27-47.

DeFrancisco, V. (1991). The sound of silence: How men silence women in marital relationships. Discourse and Society, 2 (4), 413-424.

Ferdie, K. (2017). Selamat Tinggal Cinta. HAI. Jakarta: Gramedia Pustaka Utama.

Gilligan, C. (1982). In a different voice: Psychological theory and women's development. Cambridge: Harvard University Press.

Kemp, R. (2014). Code switching among men and women. Retrieved from http://languageasculturespring11.com/2011/0 3/code-switching-among-men-andwomen.html

Janssen, A. M. (2005). Readers' perceptions of author gender and literary gender. Journal of Language and Social Psychology, 207-219.

Maltz, D., \& Borker, R. (1982). A cultural approach to male-female communication. Journal of Language and Social Psychology, 181-203.

Mulac, A., \& Lundell, T. L. (1994). Effects of gender-linked language differences in adults' written discourse: Multivariate tests of language effects. Language and Communication, 14, 299-309.

Safira, N. (2017). Effortlessly beautiful. $K A W A N K U$. Jakarta: Gramedia Pustaka Utama.

Shaik, M. S., \& Khan, U. (2012). Contructing gender identities in discourse: A critical discourse analysis of two short stories. American International Journal of Contemporary Research, 2(3), 153-160.

\section{PROFIL PENULIS}

Dwi Indarti, S.S., M.Hum. finished the Undergraduate School (S1) of STIBA NUSA MANDIRI, Jakarta, majoring in English Literature and Graduate School (S2) of Universitas Katolik Atma Jaya Jakarta, majoring in Applied English Linguistic. Recent activities are working in a mining company located in SCBD Senayan Jakarta and teaching in ABA-BSI Salemba 45 Jakarta. 